\title{
Uji In Vitro Keefektifan Ekstrak Air Daun Dan Bunga Kembang Telang (Clitoria ternatea l.) terhadap Jamur Alternaria solani Penyebab Penyakit Bercak Coklat pada Tanaman Tomat
}

\author{
Tarkus Suganda*, Pini Komalasari, Endah Yulia, dan W. Daradjat Natawigena \\ Departemen Hama dan Penyakit Tumbuhan Fakultas Pertanian Universitas Padjadjaran \\ Jl. Raya Bandung-Sumedang KM 21 Jatinangor Jawa Barat 45363 \\ *Alamat korespondensi: tarkus.suganda@gmail.com
}

\begin{abstract}
In vitro effectiveness test of aqueous extracts of leave and flower of butterfly pea (Clitoria ternatea L.) against Alternaria solani the incitant of early blight of tomato
\end{abstract}

Early blight (Alternaria solanı) in one of the most destructive diseases of tomato. Yield loss due to the disease may reach up to $78 \%$. It is mostly controlled by fungicide application but besides detrimental and hazzardous effect of fungicide on environment, this pathogen is able to evolve to be less sensitive to synthetic fungiside and even builts a cross resistance to several active ingredients. Some studies reported that plant extracts can suppress various pathogens. Butterfly pea is known to have antimicrobial properties against various microorganisms. The aim of this study was to determine the effectiveness of aqueous extract of butterfly pea's leave and flower in supressing $A$. solani in vitro. The experiment used the experimental method with Completely Randomized Design, consisted of four concentrations of aquaeous estract of leaf $(0,3,6$, dan $9 \%)$ and four concentrations of aquaeous extract of flower $(0,5,10,15 \%)$ that were based on the LC50 from initial inhibition test. The results showed that leaves and flowers extracts supressed the growth of the fungus $A$. solani colonies. The highest suppresion of leaves and flower aqueous extract were at the concentrations of $9 \%(34.78 \%)$ and 15\% (38.97\%), respectively. Aqueous extract of leaves reduced the conidial production of $A$. solani at concentration of $9 \%$, resulted in $3.0 \times 10^{3}$ conidia/ml, whereas the concentration of $15 \%$ of flower aqueous extract inhibited conidial production completely. The highest inhibition on conidial germination showed by the concentration of $3 \%$ of leaf extract $(58.33 \%)$ and by the concentration of $5 \%$ of flower extract (75.00\%). The antisporulant effect of leaf and flower aqueous extract of butterfly pea was more prominent that its fungistatic or its fungicidal effects.

Key words: Clitoria ternatea, aqueous extract, Alternaria solani, in vitro

\begin{abstract}
ABSTRAK
Penyakit bercak coklat (Alternaria solanı) merupakan salah satu penyakit yang sangat merugikan pada tanaman tomat. Umumnya penyakit ini dikendalikan dengan penggunaan fungisida sintetik, tetapi selain menyebabkan dampak buruk bagi lingkungan, patogen ini juga mampu berubah menjadi tidak sensitif lagi terhadap bahan aktif fungisida sintetik yang digunakan. Beberapa penelitian melaporkan bahwa ekstrak tumbuhan dapat menekan berbagai patogen. Tanaman kembang telang diketahui memiliki sifat antimikroba terhadap berbagai mikroorganisme. Penelitian ini bertujuan untuk mengetahui kemampuan ekstrak air daun dan bunga kembang telang dalam menekan $A$. solani secara in vitro. Percobaan dilakukan dengan metode eksperimen menggunakan Rancangan Acak Lengkap terdiri atas empat konsentrasi ekstrak daun (0, 3, 6, dan $9 \%)$ dan empat konsentrasi ekstrak bunga $(0,5,10,15 \%)$ yang diperoleh berdasarkan uji LC50 pendahuluan. Hasil percobaan menunjukkan bahwa ekstrak air daun maupun bunga memperlihatkan penekanan terhadap pertumbuhan koloni jamur A. solani. Penekanan tertinggi ekstrak air daun maupun bunga masing-masing pada konsentrasi 9\% (34,78\%) dan 15\% (38,97\%). Ekstrak air daun mampu menurunkan produksi konidia $A$. solani pada konsentrasi $9 \%$ yaitu 3,0 x
\end{abstract}


$10^{3} \mathrm{konidia} / \mathrm{ml}$, sementara pada konsentrasi 15\%, ekstrak air bunga kembang telang menekan total produksi konidia $A$. solani. Penghambatan tertinggi terhadap perkecambahan konidia (58,33\%) ditunjukkan oleh ekstrak air daun kembang telang $3 \%$ sedangkan oleh ekstrak air bunga kembang telang sebesar 75,00\% oleh konsentrasi 5\%. Kemampuan antisporulasi dari ekstrak air daun dan bunga kembang telang lebih dominan dibandingkan kemampuan fungistatik maupun kemampuan fungisidalnya.

Kata kunci: Clitoria ternatea, ekstrak air, Alternaria solani, in vitro

\section{PENDAHULUAN}

Penyakit bercak coklat yang disebabkan oleh jamur Alternaria solani merupakan salah satu penyakit utama pada tanaman tomat. Kehilangan hasil tahunan yang diakibatkannya dilaporkan mencapai 79\% di Amerika Serikat, Australia, Israel, Inggris dan India (Gulzar et al., 2018). Jamur ini dapat menyerang seluruh stadia pertumbuhan tanaman tomat. Jika menyerang bibit, A. solani menyebabkan gejala busuk pangkal batang dan menyebabkan kematian bibit sampai 40\% (Sherf \& MacNab 1986). Pada tanaman dewasa, jamur ini menyerang mulai dari daun terbawah, sehingga penyakitnya dinamakan early blight, daun mengering dan defoliasi (Batista et al., 2006). Jika menyerang buah, $A$. solani menyebabkan gejala bercak coklat melingkar dan jika menyerang batang dan ranting menyebabkan gejala lesi (Gulzar et al., 2018). Jika pun tanaman tomat bertahan hidup dan menghasilkan buah, maka buah yang terserang, selain akan gugur sebelum matang, juga tidak akan laku untuk dipasarkan (Chairani \& Voorips, 2006).

Pengendalian penyakit bercak coklat memerlukan strategi pengendalian terpadu meliputi penggunaan varietas resisten, cara kultur teknik, dan pengaplikasian fungisida sintetik (Gudero et al., 2018). Namun A. solani dilaporkan memiliki variabilitas genetik yang luas (Leiminger et al., 2013) sehingga memudahkannya beradapatsai terhadap resistensi varietas dan bahan aktif fungisida (van der Waals et al., 2004). Nottensteiner et al. (2019) dan Derpmann \& Mehl (2019) melaporkan bahwa $A$. solani telah menunjukkan resistensi silang terhadap fungisida berbahan aktif QoI (quinone outside inhibitor) dan SDHI (succinate dehydrogenase inhibitor).

Oleh karena itu, diperlukan pencarian alternatif pengendalian yang dapat digunakan sebagai bagian dari strategi pengendalian terpadu maupun sebagai alternatif bagi pengendalian dengan fungisida sintetik. Pergiliran penggunaan senyawa kimia dengan bahan aktif yang berbeda dilaporkan dapat menunda munculnya resistensi patogen sehingga memperpanjang masa efektif suatu bahan aktif fungisida (Hahn, 2014; Fleury, 2016; Kousik et al., 2017). Salah satu taktiknya adalah dengan menggunakan senyawa kimia nabati (Abdallah, 2011; Byuhan \& Das, 2012).

Tanaman kembang telang (Clitoria ternatea L.) diketahui memiliki sifat antimikroba (Mukherjee et al., 2008; Kamilla et al., 2009; Uma et al., 2009). Ekstrak metanol bunga dari kembang telang memiliki daya hambat yang tinggi terhadap beberapa jamur (Bishnupada et al., 2011) dan bakteri seperti terhadap Candida albicans (Kamilla et al., 2009), Aspergillus niger dan Alternaria solani (Naz et al., 2013) dan Staphylococcus aures (Pahune et al., 2013).

Suganda \& Adhi (2017) melaporkan bahwa ekstrak air bagian bunga tanaman kembang telang pada konsentrasi $5 \%$ juga menunjukkan penghambatan terhadap pertumbuhan Fusarium oxysporum f.sp. cepae sebesar $46 \%$ secara in vitro. Uji in vitro keefektifan suatu senyawa kimia terhadap jamur biasanya dilakukan terhadap pertumbuhan koloni (Guarro et al., 1997; Talibi et al., 2012), serta terhadap produksi konidianya (HuuPhong et al., 2018). Tulisan ini melaporkan hasil pengujian in vitro ekstrak air bagian daun dan bunga dari tanaman kembang telang dalam menghambat pertumbuhan koloni serta produksi dan perkecambahan konidia jamur $A$. solani.

\section{BAHAN DAN METODE}

Uji in vitro dilaksanakan di Laboratorium Fitopatologi Departemen Hama dan Penyakit Tumbuhan Fakultas Pertanian Universitas Padjadjaran, pada bulan September 2019 sampai Januari 2020. Daun dan bunga kembang telang diambil dari Kebun Percobaan Ciparanje, Kecamatan Jatinangor, Kabupaten Sumedang, Provinsi Jawa Barat, yang merupakan koleksi dari Dr. Agung 
Karuniawan, dosen Departemen Budidaya Tanaman Fakultas Pertanian Universitas Padjadjaran.

\section{Pembuatan ekstrak air bagian daun dan bunga kembang telang}

Daun dan bunga tanaman kembang telang diperoleh dari lapangan dicuci bersih dengan air mengalir dan kemudian ditiriskan dalam suhu kamar. Pembuatan ekstrak air untuk masing-masing konsentrasi dibuat dengan cara menimbang daun kembang telang masing-masing seberat 7,5 g; 15,0 g; dan 22,5 g. Sementara untuk bunga ditimbang masing-masing seberat $12,5 \mathrm{~g} ; 25,0 \mathrm{~g}$; dan $37,5 \mathrm{~g}$. Daun maupun bunga kemudian dihaluskan menggunakan mortar steril secara terpisah dan ditambahkan akuades steril secukupnya. Ekstrak yang dihasilkan kemudian disaring menggunakan kertas saring Whatman No.1 lalu ditambah dengan akuades steril sampai ekstrak yang dihasilkan mencapai volume $50 \mathrm{ml}$. Selanjutnya, masingmasing ekstrak dicampur dengan media PDA cair sebanyak $200 \mathrm{ml}$ sehingga total volume mencapai $250 \mathrm{ml}$. Sebelum dicampurkan, media PDA yang digunakan diberi antibiotik kloramfenikol dengan konsentrasi 100 mg/l medium agar.

\section{Uji penghambatan pertumbuhan koloni}

Uji penghambatan ekstrak air daun kembang telang terhadap pertumbuhan koloni jamur $A$. solani secara in vitro dilakukan dengan menggunakan metode poison food (Tapwal et al., 2011). Percobaan terdiri atas 4 perlakuan ekstrak air daun dan bunga kembang telang hasil uji pendahuluan untuk mendapat konsentrasi LC50. Berdasarkan hasil uji pendahuluan untuk mendapatkan LC50 diperoleh konsentrasi ekstrak air daun yang diuji terdiri atas: $0 \%$ (kontrol tanpa ekstrak), 3\%, 6\%, dan 9\%, sementara untuk ekstrak air bunga kembang telang terdiri atas: 0\% (kontrol tanpa ekstrak), 5\%, 10\%, dan $15 \%$.

Pengujian dilakukan dengan menuangkan campuran ekstrak dan PDA masing-masing konsentrasi di atas ke dalam petridish sekitar $10 \mathrm{ml}$. Selanjutnya, media diinokulasi dengan potongan biakan jamur $A$. solani yang diambil dengan cork borer berukuran diameter $0,5 \mathrm{~cm}$ dari ujung biakan yang sedang tumbuh. Potongan biakan $A$. solani diletakan di tengah-tengah agar biakan perlakuan. Semua biakan kemudian diinkubasikan dalam suhu ruang dan ditata menggunakan Rancangan Acak Lengkap (RAL).

Pengamatan dilakukan setiap hari sampai pertumbuhan $A$. solani pada perlakuan kontrol memenuhi seluruh petridish. Semua perlakuan percobaan dilakukan dengan masing-masing tujuh ulangan.

Pengamatan penghambatan pertumbuhan koloni jamur dilakukan dengan mengukur diameter pertumbuhan koloni jamur pada masing-masing perlakuan. Pengukuran diameter dilakukan pada titik yang sama menggunakan penggaris. Pengamatan dilakukan setiap hari sampai petridish pada perlakuan $0 \%$ (kontrol) penuh. Perhitungan presentase penghambatan menggunakan rumus sebagai berikut:

Persen penghambatan

$=\frac{\text { diameter kontrol }- \text { diameter perlakuan }}{\text { dimeter kontrol }} \times 100 \%$

\section{Uji terhadap produksi konidia}

Untuk menguji pengaruh ekstrak air dari masing-masing bahan terhadap produksi konidia $A$. solani, penghitungan kerapatan konidia dilakukan pada 10 hari setelah inkubasi. Kerapatan konidia masing-masing perlakuan dihitung dengan cara mengambil 10 potong biakan $A$. solani menggunakan pembor gabus kemudian dimasukan ke dalam masing-masing tabung reaksi berisi air akuades sebanyak $10 \mathrm{ml}$ (Rosanti dkk., 2014). Tabung reaksi divortex selama 3 menit untuk melepaskan konidia. Kerapatan konidia jamur hasil suspensi dihitung dengan cara mengambil $100 \mu$ suspensi menggunakan mikro pipet dan diteteskan pada slide haemocytometer untuk selanjutnya diamati menggunakan mikroskop.

Penghitungan kerapatan konidia $A$. solani dilakukan dengan menghitung 4 kotak sampel pada haemocytometer dan dihitung kerapatannya menggunakan rumus sebagai berikut (Provost \& Wallert Research, 1998):

\section{Konidia/ml $=\mathrm{X} \cdot \mathrm{F}_{\mathrm{p}} \cdot 10^{4}$}

\section{Keterangan:}

$\mathrm{X}=$ Rata-rata konidia dari kotak sampel yang diamati

$\mathrm{F}_{\mathrm{p}}=$ Faktor pengenceran

\section{Uji terhadap perkecambahan konidia}

Uji perkecambahan konidia $A$. solani seperti yang dilakukan Widhayasa dkk., (2014). Ekstrak air daun maupun bunga kembang telang dengan masing-masing konsentrasi dimasukan ke dalam tabung reaksi sebanyak $5 \mathrm{ml}$. Sebagai perlakuan kontrol ditambahkan akuades steril. Kemudian, 
konidia dimasukan ke dalam tabung reaksi setiap perlakuan ekstrak yaitu dengan cara mengambil 5 potongan biakan murni $A$. solani berumur 14 hari menggunakan pembor gabus, selanjutnya divortex selama 3 menit untuk melepaskan konidia. Hasil suspensi pada tabung reaksi diambil menggunakan mikro pipet sebanyak $1 \mathrm{ml}$ dan diteteskan pada gelas arloji, kemudian inkubasi dalam boks steril yang diberi tisu lembab. Pengamatan dilakukan setelah 24 jam inkubasi dan diamati perkecambahannya menggunakan mikroskop pada perbesaran 400x.

Pengamatan dilakukan terhadap jumlah konidia yang berkecambah. Konidia dikatakan berkecambah apabila terbentuk tabung kecambah yang panjangnya setengah dari diameter konidia (Steinkellner et al., 2005). Presentase perkecambahan konidia dihitung dengan menggunakan rumus sebagai berikut:

$$
\mathrm{K}=\frac{\sum \text { kontrol }-\sum \text { perlakuan }}{\sum \text { kontrol }} \times 100 \%
$$

Keterangan:

$\mathrm{K}=$ presentase perkecambahan

$\Sigma$ kontrol $=$ jumlah kondia yang berkecambah pada kontrol

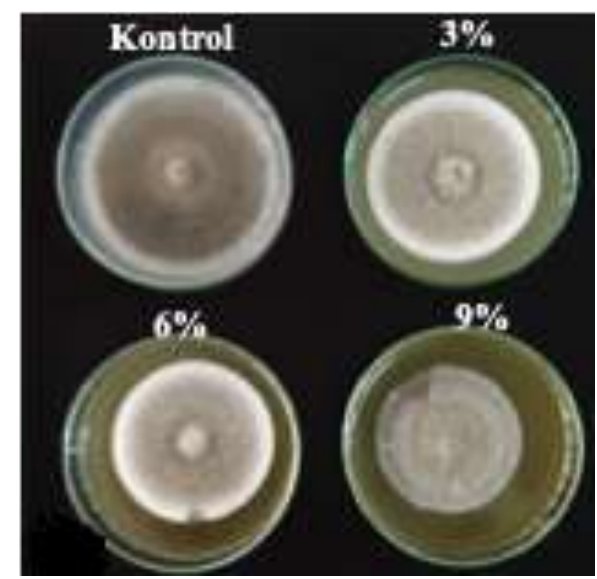

Daun $\sum$ perlakuan= jumlah konidia yang berkecambah pada setiap perlakuan

\section{Analisis statistik}

Data yang diperoleh dianalisis dengan Anova menggunakan program SPSS versi 16.0, yang dilanjutkan dengan uji Duncan pada taraf nyata 5\%.

\section{HASIL DAN PEMBAHASAN}

Penghambatan ekstrak air daun dan bunga kembang telang terhadap pertumbuhan koloni jamur $A$. solani Hasil pengujian pengaruh ekstrak air daun dan bunga kembang telang dalam menghambat pertumbuhan koloni jamur $A$. solani disajikan pada Gambar 1. Hasil pengujian (Tabel 1) menunjukkan bahwa ekstrak air daun kembang telang secara signifikan mampu menghambat pertumbuhan koloni jamur A. solani. Presentase penghambatan koloni terhadap jamur $A$. solani dari tertinggi sampai terendah yaitu pada konsentrasi $9 \%$ (34,78\%), konsentrasi $6 \% \quad(24,00 \%)$ dan konsentrasi $3 \%$ (20,16\%). Berdasarkan hasil uji statistik, semua konsentrasi yang diuji menunjukkan perbedaan yang nyata.

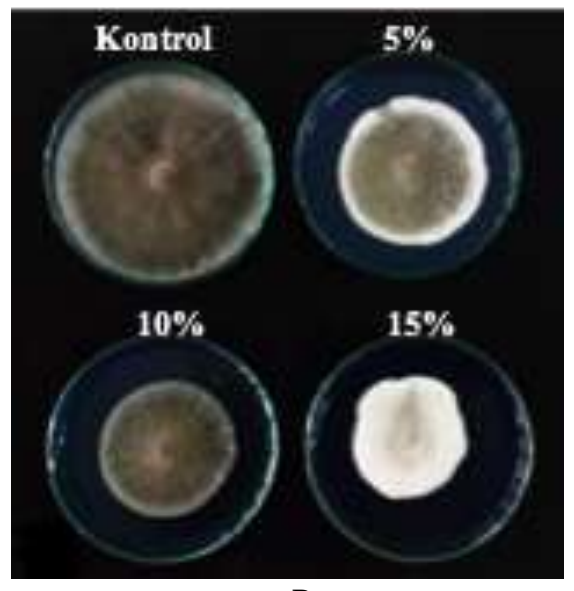

Bunga

Gambar 1. Pertumbuhan koloni jamur A. solani pada medium PDA yang dicampur dengan masing-masing konsentrasi ekstrak air daun (kiri) dan bunga (kanan) kembang telang.

Ekstrak air bunga kembang telang menunjukkan presentase penghambatan terhadap koloni jamur $A$. solani dari tertinggi sampai terendah yaitu pada konsentrasi $15 \%(38,97 \%)$, konsentrasi $10 \%$ (38,41\%), dan konsentrasi $5 \%$ $(28,73 \%)$.

Secara umum, semakin tinggi konsentrasi ekstrak air daun maupun bunga kembang telang, presentase penghambatan pertumbuhan koloni jamur A. solani juga semakin meningkat. Peningkatan presentase penghambatan oleh ekstrak tanaman terhadap beberapa jamur pada konsentrasi yang semakin tinggi juga telah banyak dilaporkan (Tapwal et al., 2011; Begum et al., 2010; Chohan et al., 2011; Ibrahim et al., 2014; Ramaiah \& Garampalli, 2015). Penghambatan oleh ekstrak air 
daun dan bunga kembang telang terhadap pertumbuhan koloni jamur patogen uji, diperkirakan disebabkan oleh karena adanya senyawa antifungal yang terkandung dalam daun dan bunga kembang telang.

Berdasarkan uji fitokimia metabolit sekunder bagian daun kembang telang mengandung tanin, cardiac glycosides, alkaloid, dan steroid (Darsini \& Shamshad, 2013). Sementara itu, pada bagian bunga mengandung phlobatanin, flavonoid, trepenoid (Kamilla et al., 2009) dan alkaloid (Darsini \& Shamshad, 2013). Senyawa metabolit sekunder tersebut telah diketahui memiliki sifat antimikroba
(Pandey \& Kumar, 2013). Oleh karena itu, menurut Kamilla et al., (2009), bagian tanaman kembang telang yang digunakan memiliki pengaruh dan keefektifan yang berbeda terhadap mikroorganisme yang diuji. Semua uji kandungan bahan aktif oleh para peneliti tersebut di atas dihasilkan melalui proses ekstraksi dengan pelarut etanol maupun metanol, sementara dalam pengujian ini ekstraksi dilakukan dengan air steril. Sepertinya, senyawa bahan aktif dalam daun dan bunga kembang telah tidak terlarutkan dalam pelarut air, sehingga kurang begitu efektif dalam menekan pertumbuhan koloni jamur A. solani.

Tabel 1. Penghambatan pertumbuhan koloni jamur $A$. solani pada perlakuan ekstrak air daun dan bunga kembang telang pada berbagai konsentrasi.

\begin{tabular}{cccc} 
Bahan yang diekstrak & Konsentrasi (\%) & $\begin{array}{c}\text { Rata-rata diameter } \\
\text { koloni (cm) }\end{array}$ & Penghambatan (\%) \\
\hline Daun & 0 & $9,00 \mathrm{~d}$ & 0 \\
Bunga & 3 & $7,19 \mathrm{c}$ & 20,16 \\
& 6 & $6,84 \mathrm{~b}$ & 24,00 \\
& 9 & $5,87 \mathrm{a}$ & 0 \\
\end{tabular}

Keterangan: Huruf yang sama pada satu kolom dalam tabel menunjukan data tidak berbeda nyata dengan kontrol berdasarkan Uji Jarak Berganda Duncan pada taraf nyata 5\%.

Pengaruh ekstrak air daun dan bunga kembang telang terhadap produksi konidia $A$. solani

Ekstrak air daun dan bunga kembang telang selain memberikan penghambatan terhadap pertumbuhan koloni jamur, juga menurunkan produksi konidia jamur $A$. solani, sebagaimana terindikasikan dari jumlah konidia yang dihasilkan. Penambahan ekstrak air daun kembang telang terhadap medium PDA menyebabkan penurunan jumlah konidia $A$. solani secara signifikan (Tabel 2). Produksi terendah konidia diperlihatkan oleh konsentrasi 9\% yaitu 3,0 x $10^{3}$ konidia/ml. Jumlah konidia pada konsentrasi ekstrak air daun kembang telah 9\% ini menurun 50\% dibandingkan dengan jumlah konidia pada perlakuan kontrol.

Tabel 2. Kerapatan konidia jamur $A$. solani pada perlakuan ekstrak air daun dan bunga kembang telang berbagai pada konsentrasi.

\begin{tabular}{ccc}
\hline Bahan yang diekstrak & $\begin{array}{c}\text { Konsentrasi } \\
(\%)\end{array}$ & Kerapatan konidia (konidia/ml) \\
\hline Daun & 0 & $6,0 \times 10^{3} \mathrm{a}$ \\
& 3 & $5,0 \times 10^{3} \mathrm{a}$ \\
& 6 & $3,5 \times 10^{4} \mathrm{a}$ \\
& 9 & $3,0 \times 10^{3} \mathrm{~b}$ \\
\hline Bunga & 0 & $9,0 \times 10^{3} \mathrm{~b}$ \\
& 5 & $7,0 \times 10^{3} \mathrm{ab}$ \\
& 10 & $2,3 \times 10^{4} \mathrm{c}$ \\
\end{tabular}

Keterangan: Huruf yang sama pada satu kolom dalam tabel menunjukan data tidak berbeda nyata dengan kontrol berdasarkan Uji Jarak Berganda Duncan pada taraf nyata 5\%. 
Sementara itu, produksi konidia yang diberi perlakuan ekstrak air bunga kembang telang penurunanya sangat signifikan. Pada konsentrasi ekstrak air bunga kembang telang 15\% (Tabel 2), produksi konidia jamur $A$. solani tidak terjadi sama sekali.

Mekanisme anti sporulasi sebagaimana ditemukan pada ekstrak air daun dan bunga kembang juga ditemukan pada penelitian lain. Chalfoun et al., (2004). melaporkan bahwa beberapa senyawa nabati dari tumbuhan obat juga bersifat anti sporulasi terhadap jamur-jamur pernghasil toksin seperti Aspergillus niger, A. flavus, dan Eurotium repens.

Hal ini diduga disebabkan oleh karena penghambatan pertumbuhan koloni jamur berpengaruh terhadap penurunan produksi konidia yang disebabkan karena kurangnya nutrisi atau adanya akumulasi zat toksik (Carlile et al., 2001). Stimulasi peningkatan jumlah konidia jamur dapat terjadi karena berbagai pengaruh, misalnya kurang tersedianya senyawa gula yang dibutuhkan untuk sporulasi seperti dilaporkan pada jamur Aspergillus flavus (Calvo et al., 2002) dan kurangnya nutrisi pada Penicillium sp. (Costa \& Nahas, 2012).

Berdasarkan data pada Tabel 2 dapat dikatakan bahwa ekstrak air tanaman kembang telang, baik dari bagian daun maupun bunga lebih bersifat sebagai anti sporulasi dibandingkan dengan fungistatik penekanan pertumbuhan koloni. Hal ini perlu dikaji lebih lanjut karena potensinya sangat bagus, mengingat jamur A. solani merupakan patogen tular udara yang penyebarannya melalui konidia. Jika dengan penyemprotan ekstrak air bunga kembang telang terhadap tanaman yang sudah terinfeksi dilakukan, maka penyebaran jamur A. solani dapat dikendalikan karena produksi konidianya terhambat.

\section{Perkecambahan konidia $A$. solani pada perlakuan} dengan ekstrak air daun dan bunga kembang telang

Pemberian ekstrak air dan bunga kembang telah sampai konsentrasi tertentu menunjukkan penekanan terhadap perkecambahan konidia jamur A. solani (Tabel 3). Namun demikian, baik untuk ekstrak air daun maupun bunga, terdapat konsentrasi optimal dalam menekan perkecambahan konidia jamur $A$. solani mengikuti kurva bentuk bel. Ekstrak daun kembang telang mampu menghambat perkecambahan konidia konidia $A$. solani. Penghambatan tertinggi diperlihatkan oleh konsentrasi 3\% (58,33\%). Namun pada konsentrasi tertinggi (9\%), ekstrak daun kembang telang justru sama sekali tidak dapat menghambat perkecambahan konidia $A$. solani, karena semua konidia berkecambah sebagaimana pada perlakuan kontrol.

Hasil yang sama juga diperlihatkan oleh perlakuan dengan ekstrak air bunga kembang telang. Penghambatan tertinggi terhadap perkecambahan konidia $A$. solani, diperlihatkan oleh ekstrak air bunga kembang telang konsentrasi 5\% (75,00\%). Namun pada konsentrasi tertinggi yang diuji (15\%), persentase perkecambahan konidia justru sama dengan pada perlakuan kontrol. Semua konidia berkecamba.

Tabel 3. Penghambatan perkecambahan konidia jamur A. solani pada perlakuan ekstrak air daun dan bunga kembang telang pada berbagai konsentrasi.

\begin{tabular}{cccc}
\hline $\begin{array}{c}\text { Bahan yang } \\
\text { diekstrak }\end{array}$ & Konsentrasi (\%) & $\begin{array}{c}\text { Rata-rata perkecambahan } \\
\text { konidia (\%) }\end{array}$ & $\begin{array}{c}\text { Penghambatan perkecambahan } \\
\text { konidia (\%) }\end{array}$ \\
\hline Daun & 0 & $100,00 \mathrm{~b}$ & - \\
& 3 & $41,67 \mathrm{a}$ & 58,33 \\
& 6 & $66,67 \mathrm{a}$ & 33,33 \\
Bunga & $100,00 \mathrm{~b}$ & $\mathrm{Tm}$ \\
\hline & 0 & $100,00 \mathrm{~b}$ & - \\
& 5 & $25,00 \mathrm{a}$ & 75,00 \\
& 10 & $83,33 \mathrm{~b}$ & 16,67 \\
\hline Keterangan: Huruf yang sama pada satu kolom dalam tabel menunjukan data tidak berbeda nyata dengan kontrol berdasarkan Uji Jarak \\
Berganda Duncan pada taraf nyata 5\%. \\
"Tm= Tidak menghambat & & \\
*- = Tidak dihitung & &
\end{tabular}


Hasil pengujian yang menunjukkan bahwa pengaruh ekstrak air, baik daun maupun bunga kembang telang mengikuti pola kurva berbentuk bel diduga disebabkan oleh keberlimpahan kandungan senyawa gula yang meningkat seiring dengan meningkatnya konsentrasi esktrak. Berdasarkan penelitian Nassr \& Barakat (2013), kandungan senyawa gula seperti glukosa, fruktosa, dan sukrosa pada konsentrasi $100 \mu \mathrm{m}$ merupakan titik puncak untuk dapat menginduksi secara signifikan perkecambahan konidia jamur Botrytis cinera. Hal ini juga dilaporkan oleh beberapa peneliti (Ibrahim et al., 2014; Yulia dkk., 2016).

Kembang telang memiliki aktivitas antijamur yang kuat terhadap Aspergillus niger dan Candida albican (Bishnupada et al., 2011). Rusaknya hifa yang menyebabkan kematian pada hifa $A$. niger merupakan salah satu mekanisme penghambatan dari pemberian ekstrak metanol daun kembang telang (Kamilla et al., 2009). Semua pengujian tentang efek fungisida dari tanaman kembang telang menggunakan pelarut etanol maupun metanol. Pada penelitian ini yang digunakan adalah ekstrak air, dengan tujuan ingin melihat aspek praktis penggunaannya. Jika efektif dengan cara ekstrak air, maka akan membantu petani dalam menyiapkan dan mengaplikasikannya. Tidak terlalu signifikannya pengaruh ekstrak air daun maupun bunga kembang telang terhadap jamur $A$. solani, nampaknya disebabkan oleh pelarut yang digunakan dalam mengekstraksi. Perbedaan pelarut yang digunakan memberikan hasil ekstraksi yang berbeda (Ngo et al., 2017; Do et al., 2014).

\section{SIMPULAN DAN SARAN}

\section{Simpulan}

Berdasarkan hasil percobaan, dapat disimpulkan bahwa:

1. Ekstrak air daun dan bunga kembang telang memiliki penghambatan yang rendah terhadap pertumbuhan koloni $A$. solani penghambatan tertinggi terjadi pada konsentrasi 9\% (34,78\%) dan ekstrak air bunga pada konsentrasi 15\% (38,97\%).

2. Ekstrak air daun dan bunga kembang telang mampu menurunkan produksi konidia jamur A. solani. Penekanan terbaik terhadap produksi konidia oleh ekstrak air daun kembang telang diperlihatkan oleh konsentrasi 9\% dengan kerapatan konidia $3,0 \quad$ x $\quad 10^{3} \quad$ konidia/ml. Sementara oleh ekstrak air bunga kembang telang penekanan terbaik diperlihatkan oleh konsentrasi $15 \%$ dengan produksi konidianya nol.

3. Ekstrak air daun dan bunga kembang telang mampu menghambat perkecambahan konidia A. solani pada konsentrasi 3\% (58,33\%) dan ekstrak air bunga 5\% (75,00\%).

4. Ekstrak air daun dan bunga kembang telang tampak lebih berfungsi sebagai anti sporulan dibandingkan dengan sebagai fungistatik atau fungisida.

\section{Saran}

Dalam penelitian untuk mengetahui efek fungisida dari ekstrak daun dan bunga kembang telang baru menggunakan air sebagai pelarut. Disarankan untuk menggunakan pelarut organik lain seperti metanol dan etanol.

\section{DAFTAR PUSTAKA}

[Provost and Wallert Research]. 1998. Hemocytometer cell counting protocol. Investigating the Biochemistry \& Cellular Physiology of NHE1. 1-2 p. Available at http://home.sandiego.edu/ josephprovost/H emocytometer\%20Cell\%20Counting\%20Pr otocol.pdf on 29/01/2019.

Abdallah, EM. 2011. Plants: An alternative source for antimicrobials. Journal of Applied Pharmaceuticals Science 01(06):16-20.

Batista, DC, MA Lima, F Haddad, LA Maffia and ESG Mizubuti. 2006. Validation of decision support systems for tomato early blight and potato late blight under Brazilian conditions. Crop Prot 25, 664-670.

Begum, MF, MF Mahaland, and Md.S Alam. 2010. Inhibition of spore germination and mycelial growth of three fruit rot pathogens using some chemical fungicides and botanical extracts. Journal of Life Earth Sciences. 1 (5): 23-27.

Calvo, AM, RA Wilson, JW Bok, and NP Keller. 2002.

Relationship between secondary metabolism and fungal development. Microbiology and Molecular Biology Reviews. 66 (3): 447-459.

Carlile, MJ, SC Watkinson, and GW Gooday. 2001. The Fungi. London: Academic Press, 588p.

Chalfoun, SM, MC Pereira, MLV Resende, CL Angelico, and RA Da Silva. 2004. Effect of powdered spice treatments on mycelial growth, sporulation and production of 
aflatoxins by toxigenic fungi. Cience e Agrotecnologia. 28 (4): 856-862.

Chohan, S, R Atiq, MA Mehmood, S Naz, B Siddique, and G Yasmin. 2011. Efficacy of few plant extracts against Fusarium oxysporum f. sp. gladioli, the cause of corm rot of gladiolus. Journal of Medicinal Plants Research. 5 (16): 3887-3890.

Costa, BO and E Nahas. 2012. Growth and enzymatic responses of phytopathogenic fungi to glucose in culture media and soil. Brazilian Journal of Microbiology. 332-340.

Darsini, IP and S Shamshad. 2013. Antimicrobial activity and phytochemical evaluation of Clitoria ternatea. International Journal Science and Research. 6 (14): 283-285.

Derpmann, J and A Mehl. 2019. SDHI crossresistance pattern of Alternaria solani field mutants and consequences for early blight control. WUR Special Report of the 17th Euroblight Workshop. Yok UK 12-15 May 2019. Pp. 87-96.

Do, QD, AE Angkawijaya, PL Tran-Nguyen, LH Huynh, FE Soetaredjo, S Ismadji, and Y-H Ju. 2014. Effect of extraction solvent on total phenol content, total flavonoid content, and antioxidant activity of Limnophila aromatica. Journal of Food and Drug Analysis 22(3): 296-302.

Fleury, D. 2016. Diseases, fungicides, and redusing risk of resistance pulses. Saskatchewan Pulse Growers.

Guarro, J, C Llop, C Aguilar, and I Pujol. 1997. Comparison of in vitro antifungal susceptibilities of conidia and hyphae of filamentous fungi. Antimicrobial Agents and Chemotherapy, Dec. 1997, p. 27602762.

Gudero, G, M Dejene, H Terefe, and A Jambo. 2018. Integrated management of early blight (Alternaria solani) in tomato (Solanum lycopersicum) in Arbamaich Areas, Southwestern Ethiopia. Pest Management Journal of Ethiopia 21:1-21.

Gulzar, N, AN Kamili, and MY Mir. 2018. The Process of Early Blight Disease Development in Tomato. Journal of Research \& Development, Vol. 18:112-115.

Hahn, M. 2014. The rising threat of fungicide resistance in plant pathogenic fungi: Botrytis as a case study. Journal of Chemical Biology 7(4):133-141.
Huu-Phong, N, W Pongnak, and K Soytong. 2018. Antifungal activities of Chaetomium spp. against fusarium wilt of tea. Plant Protection Science vol. 52 No. 1:10-17.

Ibrahim. M, K Shehu, IY Tafinta, UA Imam, and YI Hassana. 2014. Efficacy of some plant extracts on growth and germination of Rhizopus stolonifer and Fusarium oxysporum isolated from rotten irish potato tubers. Annals of Biological Sciences. 2 (3): 63-67.

Kamilla, L, SM Mnsor, S Ramanathan, and S Sasidharan. 2009. Antimicrobial activity of Clitoria ternatea (L.) extracts. Pharmacologyonline. 1: 731-738.

Kousik, CS, P Ji, DS Egel, LM Quesada-Ocampo. 2017. Fungicide rotation program for managing Phytophthora fruit rot of watermelon in Southeastern United States. Plant Health Progress 18:26-34.

Leiminer, JH, H-J Auinger, M Wening, G Bahnweg, and H Haunsladen. 2013. Genetic variability among Alternaria solani isolates from potatoes in Southern Germany based on RAPD-profiles Journal of Plant Diseases and Protection 120(4):164-172.

Mukherjee, PK, V Kumar, NS Kumar, and M Heinrich. 2008. The ayurvedic medicine Clitoria ternatea from traditional use to scientific assessment. Journal Ethnopharmcol. 120: 291-301.

Naz, S. 2013. Antifungal activity of Clitoris ternatea L. extracts against different fungal species. Journal of Mycopathologia. 11 (2): 91-94.

Ngo, TV, CL Scarlett, MC Bowyer, PD Ngo, and QV Vuong. 2017. Impact of different extraction solvents on bioactove compounds and antioxidant capacity from the root of Salacia chinensis L. Hindawi Journal of Food Quality, Article ID 9305047, 8 pp.

Nottensteiner, M, C Absmeier and M Zellner. 2019. QoI fungicide resistance mutations in Alternaria solani and Alternaria alternata are fully established in potato growing areas in bavaria and dual resistance against SDHI fungicides is upcoming. Gesunde Pflanzen. Online. https://doi.org/10.1007/s10343-01900475-5.

Pahune, B, K Niranjane, K Danao, M Bodhe, and V Rokade. 2013. Antimicrobial Activity of Clitoria ternatea L. flower extract and use as a natural indicator in acid base titration. 
Journal of Natural Product and Plant Resources. 3 (2): 48-51.

Pandey, AK and S Kumar. 2013. Prespective on plant product as an antimicrobial agent: a review. Pharmacologia. 4 (7): 469-480.

Rahmatzai, N, AA Zaitoun, MH Madkour, A Ahmady, Z Hazim, and MAA Mousa. 2016. Morphological, pathogenic, cultural and physiological variability of the isolates of Alternaria solani causing early blight of tomato. International Journal of Advanced Research: 4 (11): 808-817.

Ramaiah, AK and RKH Garampalli. 2015. In vitro antifungal activity of some plant extracts against Fusarium oxysporum f. sp. lycopersici. Asian Journal of Plant Science and Research. 5 (1): 22-27.

Rosanti, KT, IR Sastrahidayat, and AL Abadi. Pengaruh jenis air terhadap perkecambahan spora jamur Colletotrichum capsici pada cabai dan Fusarium oxysporum pada tomat. Jurnal Hama Penyakit Tumbuhan. 2 (3): 109-120.

Suganda, T dan SR Adhi. 2017. Uji pendahuluan efek fungisida bunga kembang telang (Clitoria ternatea L.) terhadap jamur Fusarium oxysporum f.sp. cepae penyebab penyakit moler pada bawang merah. Jurnal Agrikultura. 28 (3): 136-140.

Talibi, I, L Askarne, H Boubaker, EH Boudyach, F Msanda, B Saadi, and AB Aoumar, A. 2012. Antifungal activity of some Moroccan plants against Geotrichum candidum, the causal agent of postharvest citrus sour rot. Crop Protection, 35, 4146.doi:10.1016/j.cropro.2011.12.016.

Tapwal, A, Nisha, S Garg, N Gautam, and R Kumar. 2011. In vitro antifungal potency of plant extracts against five phytopathogens. Brazilian Archives of Biology and Technology 54(6):1093-1096.

Uma, B, K Prabhakar and S Rajendran. 2009. Phytochemical analysis and antimicrobial activity of Clitoria ternatea Lin. Againts spectrum beta lactamase producing enteric an urinary phatogens. Asian Journal of Pharmaceutical and Clinical Research. 2(4): 94-96.

van der Waals, JE, L Korsten, and B Slippers. 2004. Genetic diversity among Alternaria solani isolates from potatoes in South Africa. Plant Dis. 88:959-964.

Widhayasa, B, IR Sastrahidayat, dan S Djauhari. 2014. Perkecambahan jamur Alternaria solani dan infeksinya pada sembilan varietas tomat. Jurnal Hama Penyakit Tumbuhan. 2 (3): 102-108.

Yulia, E, F Widiantini, A Purnama, dan I Nurhelawati. Keefektifan ekstrak air daun binahong (Anredera cordifolia (ten.) Steenis) dalam menekan pertumbuhan koloni dan perkecambahan konidia jamur Colletotrichum capsici penyebab penyakit antraknos pada cabai. Jurnal Agrikultura. 27 (1): 16-22. 